\title{
Lorsban-Induced Changes in Haematological and Some Reproductive Parameters of Male Rats
}

\begin{abstract}
The present study was carried out to investigate the possible toxic effects of different doses of lorsban on blood hematology, testosterone and thyroxin levels, and semen quality of male rats. Lorsban was given to rats by oral route at different doses $(5,10$ and $15 \mathrm{mg} / \mathrm{kg} \mathrm{bw} / \mathrm{day})$ for 6 weeks. The obtained results showed that all three doses of lorsban caused significant changes in the body weight gains and body weight. Relative weights of testes, epididymal and seminal vesicles were significantly $(P<0.05)$ decreased in rats receiving $15 \mathrm{mg} / \mathrm{kg}$ only. Also, there was a decrease in mean corpuscular hemoglobin (MCH) and in mean corpuscular volume (MCV) in all experimental animals compared to control ones. While, there were insignificant changes in white blood cells (WBC), hemoglobin (Hb), hematocrit value $(\mathrm{Ht})$, mean cell hemoglobin concentration (MCHC) and red blood cells (RBC) for rats treated with lorsban compared to control group. Meanwhile, it appeared that lorsban caused a rise in thrombocyte (PL) number in individuals treated with the highest dose. Similarly, the highest dose induced significant $(p<0.001)$ decrease in spermatids number, sperm count and sperm transit rate with an observed impairment of daily sperm production. Such observations were coupled with a reduction in plasma testosterone levels and an increase in plasma free thyroxin (FT4) levels compared to controls. It is, therefore, assumed that treatment with lorsban up to 15 $\mathrm{mg} / \mathrm{kg}$ bw alters both hematological and reproductive parameters in rats, and subsequently affects fertility.
\end{abstract}

Key words: Rats, lorsban, haematological parameters, semen quality, testosterone, thyroxin

\section{INTRODUCTION}

To meet the needs of an ever-increasing population, a variety of pesticides are widely used in agriculture to combat plagues of diverse crops, increasing productivity and quality of agricultural products. By their nature and their presence in food, water and environment, pesticides are harmful to some forms of life and at certain levels of exposure they may be harmful to humans (Presibella et al., 2005).

Previous studies have shown that exposure to insecticides caused alterations in haematological parameters, and endocrine and reproductive systems (Yousef et al., 2003a, b; El-Demerdash et al., 2004). Haratym-Maj (2002) has shown that pyrethroids $(\alpha-$

\footnotetext{
${ }^{1}$ Department of Environmental Studies, Institute of Graduate Studies \& Research, University of Alexandria, Egypt

2 Department of Home Economics, Faculty of Specific Education,

University of Alexandria, Egypt

Received November11, 2007, Accepted December30 2007
}

cypermethrin, deltamethrin and fenvalerate) may cause a mobilization of the hemopoietic system, manifested by a higher level of erythrocytes, hemoglobin concentrations and hematocrit as well as leucocytes and monocytes.

Lorsban is a well known insecticide and its active substances are cypermethrin $(20 \mathrm{~g} / \mathrm{l})$ and chlorpyriphosethyl $(200 \mathrm{~g} / \mathrm{l})$. Cypermethrin is extensively used as an ectoparasiticide in animals and as insecticide in crop production and public health programme. At higher doses, cypermethrin can affect the nervous system, decrease growth, increase liver and kidney weights (WHO, 1992). Also, it has been shown that cypermethrin induces moderate toxic effects on blood elements and on some of the biochemical functions, including lipoproteins, protein, urea, creatinine, glucose, and total bilirubin in rabbits (Yousef et al., 2003a). In addition, Yousef et al. (2003b) showed that cypermethrin induced pronounced hazardous effects in several physio-metabolic functions including body weight, feed intake, testosterone levels and reproductive performance of male rabbits.

Chlorpyriphos-ethyl is a broad-spectrum organophosphorus pesticide used as an insecticide to control household pests, aquatic larvae, mosquitoes, flies, various crop pests in soil and on foliage. It is also used on sheep and cattle for control of ectoparasites (Hayes and Laws, 1991). The toxicity of chlorpyriphos is specifically attributed to the inhibition of the enzyme acetylcholinesterase (Ecobichon, 1996). Previous studies conducted on male rats revealed a decrease in body weight and red blood cell count, increase in platelet count, reduced in serum total protein, albumin and globulin concentrations. A decrease in serum alkaline phosphatase and alanine aminotransferases activities have also been noted (WHO, 1999). However, some reproductive toxicity studies on chlopyriphos showed very weak effects on parental reproductive function or no apparent neonatal toxicity in offspring (Ashry et al., 1994; Breslin et al., 1996).

In spite of lorsban is a widely used insecticide, but to our knowledge there are no enough published data showing the effects of this compound on various hematological parameters and reproductive performance 
of male rats. Therefore, the present study aimed to investigate the hematological and reproductive toxicity of lorsban in male rats.

\section{MATERIALS AND METHODS}

\section{Chemicals and Animals}

Lorsban (22\% EC) is a mixture of two insecticides, cypermethrin $(20 \mathrm{~g} / \mathrm{l})$ and chlorpyriphos-ethyl $(200 \mathrm{~g} / \mathrm{l})$. Cypermethrin [( $\boldsymbol{\alpha}$-cyano-3-phenoxybenzyl 3 (2-2dichlorvinyl)-2-2-dimethylecyclopropane carboxylate), (C22 H19 Cl2NO3)] is a synthetic pyrethroid. Chlorpyriphos-ethyl [O, O,-diethyl O-(3,5,6-thrichloro2pyridinyl) phosphorothioate (C9H11Cl3NO3PS)] is a OP compound (WHO, 1992).

Male wistar rats of 4 months of age were used in the present study, with a mean body weight of $350 \mathrm{~g}$. Rats were kept singly in plastic cages and received a standard pellet feed and water ad libitum. The animals were randomly divided into four groups each of 8 rats.

\section{Lorsban pesticide administration}

Lorsban was initially diluted in water. Lorsban was given daily to rats by oral route throughout the six weeks experimental period. Treatment period was 6 weeks to cover complete reproductive cycle. Animals of groups 2, 3 and 4 received respectively doses of $5 \mathrm{mg} / \mathrm{kg}$ bw, $10 \mathrm{mg} / \mathrm{kg}$ bw and $15 \mathrm{mg} / \mathrm{kg}$ bw, while those of group 1 served as control. The dose was adjusted weekly according to the average body weight of the group.

\section{Body and sex organ weights}

Daily body weight, and feed and water intake were recorded weekly throughout the study period. At the end of the treatment period, animals were sacrificed and the male reproductive organs (testes, epididymis, seminal vesicles) were quickly removed and weighed individually and then relative organ weights were calculated.

\section{Haematological analysis}

At the end of the experimental period, blood samples were collected by decapitation and placed immediately on ice. EDTA was used as an anticoagulant for determination of selected haematological parameters. Red blood cell (RBC) counts, white blood cell (WBC), haematocrit value (packed cells volume; PCV) and haemoglobin $(\mathrm{Hb})$ level were measured using automatic ABACUS counter (Abacus haematology analyzer DIATRON Messtechnik Ges.m.b.H. A-1141 Wien, Ameisgasse 49-51/2. AUSTRIA). The following parameters were calculated: mean corpuscular haemoglobin $(\mathrm{MCH})$, mean corpuscular haemoglobin concentration (MCHC) and mean corpuscular volume (MCV) were calculated.

\section{Sperm and spermatid number:}

The left testis and epididymis from each rat were excised and cleared off the attached and connective tissue and weighed. After removal of tunica albuginea the testis was minced with scissors and homogenized in $10 \mathrm{ml} 0.9 \% \mathrm{NaCl}$ containing $0.5 \%$ Triton $\mathrm{X}-100$; the homogenate was mixed using vortex mixer. The number of homogenization-resistant spermatids was counted in haemocytometer (Mallassez) chamber. Daily sperm production (DSP) was calculated by dividing the number of homogenization-resistant spermatid by 6.1 (Robb et al., 1978; Blazak et al., 1993).

The cauda epididymis was cut into small pieces by a disposable blade in $10 \mathrm{ml}$ of $0.9 \% \mathrm{NaCl}$ containing 0.5 $\%$ Triton $\mathrm{X}-100$ and homogenized and spermatozoa were counted as described above. The epididymal sperm transit rate was estimated for each male rat by dividing the epididymal sperm number by the daily sperm production (Amman et al., 1976).

\section{Hormones analysis}

Blood samples were centrifuged at $2500 \mathrm{rpm}$ for 15 min and plasma was stored at $-20^{\circ} \mathrm{C}$ for later analyses. Plasma testosterone and free thyroxin (FT4) concentrations were measured using the enzyme immunoassay (ELISA) kit purchased from DRG diagnostics, GmbH, Germany.

\section{Statistical analysis}

Data were analyzed as a completely randomized design (Steel and Torrie, 1981) using the General Linear Model procedure of SAS (1986). Means were statistically compared using Least Significant Difference (LSD) test (Steel and Torrie, 1981).

\section{RESULTS AND DISCUSSION}

\section{Body weight and organs weight}

As shown in Table 1, there has been decrease in body weight of animals treated with $15 \mathrm{mg} / \mathrm{kg}$ of lorsban, compared to control rats during the first experimental week, while there has been a slight increase in body weight of the same animals at the end of the experimental period. Yet, body weights gain was less pronounced in the other treated animals compared to the control ones. Also, lorsban caused significant changes in body weight during the treatment period (Table 1). In addition, there were significant $(\mathrm{P}<0.05)$ reduction in testes, epididymis and seminal vesicles weights only in rats treated with the highest dose compared to control rats (Table 2). While, treatment with doses of lorsban did not cause significant changes in the weights of liver, kidney and spleen compared to control (Table 2).

\section{Hematological parameters}

Changes in blood parameters in both control and 
Table 1. Effect of lorsban on body weight (g) and weight gain (g/day) of adult male rats during the experimental period

\begin{tabular}{lcccc} 
Day/week & Control & $\mathbf{5 m g} / \mathbf{k g}$ & $\mathbf{1 0 m g / k g}$ & $\mathbf{1 5 m g / k g}$ \\
\hline Day 1 $^{\mathbf{a}}$ & $302 \pm 1.8$ & $317 \pm 2.4$ & $345 \pm 0.9$ & $360 \pm 2.9$ \\
Day 7 $^{\mathbf{a}}$ & $328 \pm 5.5^{* *}$ & $338 \pm 5.1^{*}$ & $346 \pm 3.4$ & $331 \pm 10.9^{* *}$ \\
Day 14 $^{\mathbf{a}}$ & $346 \pm 5.5^{* *}$ & $349 \pm 4.7^{* *}$ & $355 \pm 3.4^{*}$ & $350 \pm 10.9^{*}$ \\
Day 21 $^{\mathbf{a}}$ & $360 \pm 5.5^{* *}$ & $358 \pm 7^{* *}$ & $365 \pm 3.4^{* *}$ & $373 \pm 9.7^{*}$ \\
Week 6 $^{\mathbf{a}}$ & $376 \pm 3.6^{* *}$ & $360 \pm 7.7^{* *}$ & $367 \pm 3.3^{* *}$ & $370 \pm 9.7^{*}$ \\
Body weight gain $^{\mathbf{b}}$ & $1.77 \pm 0.28$ & $1.02 \pm 0.16^{* *}$ & $0.53 \pm 0.1^{* *}$ & $0.24 \pm 0.21^{* *}$ \\
\hline
\end{tabular}

Results are expressed as mean \pm standard error. ${ }^{\text {a}}$ Statistically significant different $(* \mathrm{P}<0.05 ; * * \mathrm{P}<0.01 ; * * * \mathrm{P}<0.001)$ from day 1 within column. ${ }^{\mathrm{b}}$ Statistically significant different $(* \mathrm{P}<0.05 ; * * \mathrm{P}<0.01 ; * * * \mathrm{P}<0.001)$ from control group within row.

Table 2. Effect of lorsban on weights of liver, kidney, spleen and reproductive organ (testes, epididymis and seminal vesicles) after 6-weeks treatment period

\begin{tabular}{lcccc}
\hline Weight $\mathbf{( g )}$ & Control & $\mathbf{5 ~} \mathbf{~ m g} / \mathbf{k g}$ & $\mathbf{1 0} \mathbf{~} \mathbf{~ g} / \mathbf{k g}$ & $\mathbf{1 5} \mathbf{~} \mathbf{g g} / \mathbf{k g}$ \\
\hline Liver & $11.14 \pm 0.532$ & $11.75 \pm 0.284$ & $11.89 \pm 0.302$ & $12.76 \pm 0.678$ \\
Kidney & $2.02 \pm 0.060$ & $1.93 \pm 0.049$ & $1.98 \pm 0.104$ & $2.54 \pm 0.049$ \\
Spleen & $0.724 \pm 0.038$ & $0.737 \pm 0.086$ & $0.758 \pm 0.083$ & $0.788 \pm 0.038$ \\
Testes & $2.88 \pm 0.38$ & $3.25 \pm 0.33$ & $3.41 \pm 0.35$ & $2.33 \pm 0.42^{*}$ \\
Epididymis & $1.087 \pm 0.079$ & $1.088 \pm 0.044$ & $1.130 \pm 0.032$ & $0.934 \pm 0.066^{*}$ \\
Seminal vesicle & $0.483 \pm 0.036$ & $0.422 \pm 0.029$ & $0.425 \pm 0.013$ & $0.372 \pm 0.007^{*}$ \\
\hline
\end{tabular}

Values are given as mean \pm SE. Statistically significant different $(* \mathrm{P}<0.05)$ from the control group.

treated groups are summarized in Table 3. It seems that treatment with lorsban caused insignificant changes in white blood cells (WBC), haemoglobin ( $\mathrm{Hb})$, hematocrit $(\mathrm{Ht})$, mean cell hemoglobin concentration (MCHC) and in red blood cell count (RBC). On the other hand, there was significant decrease in mean corpuscular haemoglobin $(\mathrm{MCH})$ and in mean corpuscular volume (MCV) in the experiment animals compared to the control at any doses. Meanwhile lorsban caused increase in thrombocyte (PL) number in group treated with the highest dose of lorsban.

\section{Semen parameters}

Spermatid number and sperm counts, daily sperm production and sperm transit rate are presented in Table 4. The lower testis and epididymis weights in group treated with lorsban at highest dose $(15 \mathrm{mg} / \mathrm{kg})$ were accompanied by the reduction in testicular spermatids count and sperm count from caudal epididymis as well as daily sperm production $(\mathrm{P}<0.001)$. In addition, the results showed a decline in sperm counts at dose 10 $\mathrm{mg} / \mathrm{kg}$ bw $(\mathrm{P}<0.01)$. Moreover, an increase in sperm transit rate $(\mathrm{P}<0.05)$ at the highest dose was recorded.

Table 3. Changes in haematological parameters of male rats orally administered lorsban for 6 weeks

\begin{tabular}{|c|c|c|c|c|}
\hline Parameters & Control & $5 \mathrm{mg} / \mathrm{kg}$ & $10 \mathrm{mg} / \mathrm{kg}$ & $15 \mathrm{mg} / \mathrm{kg}$ \\
\hline $\operatorname{RBC}\left(10^{12} / I\right)$ & $9.0 \pm 0.32$ & $9.0 \pm 0.52$ & $8.7 \pm 0.74$ & $8.0 \pm 0.52 *$ \\
\hline HB (g/dl) & $15 \pm 0.36$ & $15 \pm 0.66$ & $14 \pm 0.87$ & $13 \pm 0.57 *$ \\
\hline Ht (\%) & $50 \pm 1.47$ & $51 \pm 2.13$ & $48 \pm 2.71$ & $47 \pm 1.57^{*}$ \\
\hline WBC $\left(10^{9} / \mathrm{l}\right)$ & $7.6 \pm 0.96$ & $8.5 \pm 0.79$ & $8.1 \pm 0.96$ & $8.7 \pm 0.97 *$ \\
\hline PL $\left(10^{9} / 1\right)$ & $603 \pm 53$ & $644 \pm 89$ & $649 \pm 73$ & $664 \pm 38^{*}$ \\
\hline $\operatorname{MCV}(f \mathbf{l})$ & $58 \pm 1.16$ & $55 \pm 2.18^{*}$ & $53 \pm 2.31 * *$ & $52 \pm 1.76^{* *}$ \\
\hline MCH (pg) & $17 \pm 0.50$ & $16 \pm 0.99 *$ & $15 \pm 0.67 *$ & $13 \pm 0.51 * *$ \\
\hline $\operatorname{MCHC~(g/dl)~}$ & $30 \pm 0.59$ & $29 \pm 1.17$ & $30 \pm 0.48$ & $28 \pm 0.49^{*}$ \\
\hline
\end{tabular}

Values are given as mean \pm standard error. Statistically significant different $(* \mathrm{P}<0.05, * * \mathrm{P}<0.01)$ from the control group. 


\section{Table 4. Effect of 6 weeks oral administration of lorsban on spermatids number, sperm count, daily sperm production (DSP) and sperm transit rate of adult male rats}

\begin{tabular}{lcccc} 
Parameters & Control & $\mathbf{5 m g} / \mathbf{k g}$ & $\mathbf{1 0 m g} / \mathbf{k g}$ & $\mathbf{1 5 m g / k g}$ \\
\hline Spermatids number $(\mathbf{x 1 0} / \mathbf{g}$ testis) & $219 \pm 33$ & $201 \pm 27$ & $190 \pm 37$ & $107 \pm 30^{* * *}$ \\
Sperm count $(\mathbf{x 1 0} / \mathbf{g}$ testis) & $139 \pm 2.1$ & $132 \pm 32.8$ & $100 \pm 21.6^{*}$ & $82 \pm 10.4^{* *}$ \\
DSP $\quad(\mathbf{x 1 0} / \mathbf{g}$ testis) & $44 \pm 5.4$ & $41 \pm 4.5$ & $39 \pm 6.1$ & $26 \pm 4.8^{* * *}$ \\
Sperm transit rate (days) & $4.07 \pm 0.57$ & $4.2 \pm 0.98$ & $4.4 \pm 0.53$ & $4.9 \pm 0.42^{*}$ \\
\hline
\end{tabular}

Results are expressed as mean \pm standard error, statistically significant different $(* \mathrm{P}<0.05 ; * * \mathrm{P}<0.01 ; * * * \mathrm{P}<0.001)$ from the control group

Daily sperm production (DSP) was calculated by dividing the number of homogenization-resistant spermatid by 6.1 .

\section{Hormone levels}

Results of the effects of lorsban on serum levels of testosterone and free thyroxin (FT4 ) after 6-week oral administration were presented in Table 5. The concentration of serum testosterone was extensively decreased $(\mathrm{P}<0.01)$ only in rats treated with the highest dose $(15 \mathrm{mg} / \mathrm{kg} \mathrm{bw})$. However, the level of FT4 was significant $(\mathrm{P}<0.05)$ increase mainly in the same group of animals.

In the present study there was a significant decrease in body weight gains of rats treated with lorsban at all doses compared with control animals. These results are in agreement with the obtained data by Elbetieha et al. (2001) and Yousef et al. (2003b).

In the present study, rats treated with lorsban showed insignificant changes in erythrocyte count, hematocrit value and hemoglobin content compared to the control group. The main haematological response of male rats to the sub-chronic exposure to lorsban pesticide was a significant decrease in $\mathrm{MCV}$ and $\mathrm{MCH}$ in any treatment and an increase in thrombocyte (PL) number (Table 3) in the group treated with the higher dose which may be due to microcytic anemia and thrombcytosis. Similarly, Ratnasooriya et al. (2002) observed a reduction in MCV in male rats treated with the pyrethroid Lambda cyalothrin at $100 \mathrm{mg} / \mathrm{kg}$ bw for 7 days. Also, Yousef et al. (2003a) reported that cypermethrin caused alterations in the haematological parameters of rabbits.

Table 5. Effect of 6 weeks oral administration of lorsban on plasma testosterone and thyroxin levels of adult male rats

\begin{tabular}{lcccc}
\hline Concentration & Control & $\mathbf{5 ~} \mathbf{~ m g} / \mathbf{k g}$ & $\mathbf{1 0} \mathbf{~} \mathbf{g g} / \mathbf{k g}$ & $\mathbf{1 5} \mathbf{~ m g} / \mathbf{k g}$ \\
\hline $\mathbf{T 4}(\mathbf{p m o l} / \mathbf{l})$ & $11.88 \pm 1.39$ & $12.21 \pm 1.55$ & $12.57 \pm 0.90$ & $14.24 \pm 0.90^{*}$ \\
Testosterone (nmol/l) & $13.07 \pm 1.19$ & $12.82 \pm 1.24$ & $12.54 \pm 1.97$ & $7.33 \pm 1.03^{* *}$ \\
\hline
\end{tabular}

The present data showed that, there was a significant reduction $(\mathrm{p}<0.05)$ in all reproductive organ weights (testes, epididymis and seminal vesicles) at the highest dose $(15 \mathrm{mg} / \mathrm{kg} \mathrm{bw})$ of lorsban. These findings are in accordance with Latchoumycandane et al. (2002) who reported that the administration of methoxychlor for 7 days in adult rats caused a reduction in the weights of the epididymis, seminal vesicles, and ventral prostate. El-Demerdash et al. (2004) noted insignificant decrease in body weight, and relative weights of brain, spleen, testes, epididymes, and heart in rats treated with fenvalerate. Also, Yousef et al. (2003b) found that rabbits gavaged with $24 \mathrm{mg} / \mathrm{kg}$ bw of cypermethrin showed a reduction in body weight and in relative weight of testes and epididymis, and serum testosterone concentrations. In deltamethrin-treated animals, the absolute and relative weights of sex accessory organs (ventral prostate and seminal vesicle) appeared to decrease in a dose-related manner. Also, testicular and epididymal absolute weights were significantly reduced in male offspring rats exposed to the highest dose of deltamethrin $(4.0 \mathrm{mg} / \mathrm{kg})$ when compared to control animals (Anderson et al., 2002). In addition, relative and absolute ovaries and the absolute seminal vesicles weights in F0 rats, and the weights of testes and ventral prostate of $\mathrm{F} 1$ were decreased at $100 \mathrm{mg} / \mathrm{kg} / \mathrm{bw}$ chlorpyriphos-methyl (Jeong et al., 2006).

The present results indicated that lorsban at dose 15 $\mathrm{mg} / \mathrm{kg} / \mathrm{bw}$ caused a significant $(\mathrm{p}<0.01)$ decrease in testis spermatid number, epidydimal sperm count and daily sperm production compared with the control animals.

Results are expressed as mean \pm standard error, $* \mathrm{P}<0.05 ; * * \mathrm{P}<0.01$ 
The observed decrease in semen characteristics could be explained by the fact that lorsban acted directly on the testes and affected the androgen biosynthesis pathway which regulates the weight, size and secretory function of testes, epididymes, seminal vesicles, ventral prostate and vas defrens. In accordance with these results, sub-lethal doses of organophosphate pesticides lead to alterations in reproductive performance in birds and mammals (Maitra and Sarkar, 1995). There are some possible mechanisms for the antigonadal action of organophosphates, they may exert a direct inhibitory action on the testis and affect androgen biosynthesis pathways, affect the pituitary gland, causing changes in gonadotrophin concentrations and thus subsequent spermatogonic impairment or they may change the concentration of neurotransmitters (Sarkar et al., 2000). Also, some authors noted a reduction in epididymal sperm counts, testicular sperm counts and daily sperm production by many pesticides. Results conducted by Yousef et al. (2003a) showed that treating rabbits with the pyrethroid cypermethrin caused a significant decline in ejaculate volume, sperm concentration, total sperm output, sperm motility, total motile sperm per ejaculate and packed sperm volume, increased the numbers of abnormal and dead sperm. Also, El-Demerdash et al. (2004) observed that fenvalerate decreased sperm concentration and motility with an increase in abnormal and dead sperm in rats.

It is clear that there is a relationship between the production of sperm, the level of testosterone and the leydig cells. The fall in serum testosterone levels in lorsban exposed rats is consistent with previous data showing alteration in leydig cells (Pino-Lataillade et al., 1995). Methoxychlor decreased serum concentration of testosterone (Lafuente et al., 2000). The study of Banbino and Hsueti (1981) suggested an interaction of pesticides with hypothalamo-pituitary gonadal axis controlling spermatogenesis and may also interact directly with sertoli or leydig cells responsible for testicular production of proteins involved in the transport and the production of testosterone.

The reduction in serum testosterone concentrations (Table 5) is in agreement with the findings conducted by Elbetieha et al. (2001) and Yousef et al. (2003b) who found that serum level of testosterone, folliculestimulating hormone and luteinzing hormone were significantly reduced in male rats and rabbits exposed to cypermethrin. Jeong et al. (2006) reported that chlopyriphos-methyl (10 or $100 \mathrm{mg} / \mathrm{kg} / \mathrm{bw})$ induced suppression of estrogen, androgen and $\mathrm{T} 4$ in dosedependency when exposed during prenatal and postnatal period until 13 weeks old in F1 male rats. Also, treatment of male rats from postnatal day 22 to 48 with atrazine $(50 \mathrm{mg} / \mathrm{kg} / \mathrm{bw})$ reduced both serum and intratesticular testosterone concentrations by approximately $50 \%$ and LH-stimulated hormone in cultured leydig cells suggests that atrazine inhibits testosterone production rather than increasing catabolism (Freidmann, 2002). These effects on testosterone were attributed to the fall in serum $\mathrm{LH}$, since LH serves as a normal stimulus for the secretion of this steroid from the testicular Lydig cells.

There is growing evidence that environmental chemicals can disrupt endocrine systems. Most evidence originates from studies on reproductive organs. However, there is also suspicion that thyroid homeostasis may be disrupted. There are few studies existing on the effects of pesticides on the thyroid function. DDT exposure of birds decreased T4 (Scollon et al., 2004). In contrast, our results showed an increase in serum FT4 level in group treated with the highest dose $(15 \mathrm{mg} / \mathrm{kg} / \mathrm{bw})$. This effect may be due to the interaction between the pesticide and thyroxine binding protein causing abnormal binding protein which involved in an increase in the level of FT4. The increase of FT4 being in accordance with reported data by Calvert et al. (1999) which showed an increment in the levels of FT4 in 278 workers employed in the manufacture of 2,4,5,-trichlorophenol contaminated with dioxin (TCDD). Hagmar (2003) reviewed 13 studies (among them 6 in neonates and infants) and showed contradictory data on the increase, decrease or no change of FT4, TT3 and TSH levels.

\section{CONCLUSION}

From the obtained results, the sub-chronic exposure to the low doses of Lorsban ( 5 and $10 \mathrm{mg} / \mathrm{kg} /$ day) did not show harmful effects on hematological and semen characteristics, and the levels on testosterone and thyroxin. While, the high dose of lorsban (15 $\mathrm{mg} / \mathrm{kg} /$ day) showed toxic effects on blood indices and fertility of male rats. Therefore, it is recommended that there must be great care when using any insecticide to control insects at home. Furthermore, crops treated or exposed to insecticides or any chemicals must not be harvested unless after 15 days from the last exposure in order to let the insecticide be degraded.

\section{REFERENCES}

Amman, R.P.; Johnson, L.; Thompson, D.L. and Pickett, B.W. (1976). Daily spermatozoal production, epididymal spermatozoal reserves and transit time of spermatozoa through the epididymides of the rhesus monkey. Biol. Reprod., 15: 586-592. 
Anderson, J.; M. Andrade.; Samanta Ara' ujo.; Gladys M. Santana.; Masahiko Ohi. and Paulo R. Dalsenter. (2002). Reproductive effects of deltamethrin on male offspring of rats exposed during pregnancy and lactation. Regulat. Toxicol. Pharmacol., 36: 310 317.

Ashry, K.M.; Ali, F.R.; Hussein, Y.A.; Hamza, S.M. and Abou-Donia, M.B. (1994). Inhibition of total and individual molecular forms of acetylcholinesterase (AChE) activity in pregnant rats and fetuses following a single oral dose of chlorpyrifos. Toxicology, 14: 910-921.

Banbino, T.H. and Hsueh A.J.W. (1981). Direct inhibitory effect of glucocorticoids upon testicular luteinizing hormone receptor and steroidogenesis in vivo and in vitro. Endocrinology, 108: 2142- 2151.

Blazak, W. F.; Trienen, K. A. and Juniewicz, P. E. (1993). Application of testicular sperm head counts in the assessment of male reproductive toxicity. In Methods in Toxiciology. 3A. Male Reproductive Toxicology (Chapin, R. E.; Heindel, J. Eds.), 86-94. Academic Press, San Diego.

Breslin, W.J.; Liberacki, A.B.; Dittenber, D.A. and Quast, J.F. (1996). Evaluation of the developmental and reproductive toxicity of chlorpyrifos in the rat. Fundam. Appl. Toxicol., 29: 119-130.

Calvert, G.M.; Sweeney, M.H. and Deddens, J. (1999). Evaluation of diabetes mellitus, serum glucose, and thyroid function among United States workers exposed to 2,3,7,8,-tetrachlorodibenzo-p-dioxin. Occup. Environ. Med., 56: 270-276.

Ecobichon, D.J. (1996). Toxic effects of pesticides. In: Klassen, C.D.; Amdur, M.O.; Doull, J. (Eds.), Casarett and Doull's Toxicology, the Basic Science of Poisons. McGraw-Hill, New York., 643-689.

Elbetieha, A.; Da'as, S.I.; Khamas, W. and Darmani, H. (2001). Evaluation of the toxic potentials of cypermethrin pesticide on some reproductive and fertility parameters in the male rats. Arch. Environ. Contam. Toxicol., 41: 522-528.

El-Demerdash, F. M.; Yousef, M. I.; Kedwany, F. S. and Baghdadi, H. H. (2004). Role of $\alpha$-tocopherol and $\beta$ carotene in ameliorating the fenvalerate-induced changes in oxidative stress, hemato-biochemical parameters, and semen quality of male rats. J. Environ. Sci. Health, 39B (3): 443-459.

Friedmann, A. S. (2002). Atrazine inhibition of testosterone production in rat males following peripubertal exposure. Reproductive Toxicology, 16: 275-279.
Hagmar, L. (2003). Polychlorinated biphenyls and thyroid status in humans. Thyroid, 13: 1021-1028.

Haratym-Maj, A. (2002). Hematological alternations after pyrethroids poisoning in mice. Ann. Agric. Environ. Med., 9: 199-206.

Hayes, W.J. and Laws, E.R. (1991). Organic Phosphorus Pesticides. In Handbook of Pesticide Toxicology. Academic Press Inc., 1039-1067.

Jeong, S.; Kim, B.; Kang, H.; Ku, H. and Cho, J. (2006). Effect of chlorpyrifos-methyl on steroid and thyroid hormones in rat F0- and F1- generations. Toxicology, 220: 189-202.

Lafuente, A.; Marquez, N.; Pousada, Y.; Pazo, D. and Esquifino, A.I. (2000). Possible estrogenic and/or antiandrogenic effects of methoxychlor on prolactin release in male rats. Arch. Toxicol., 74: 270- 281.

Latchoumycandane, C.; Chitra, K.C. and Mathur, P.P. (2002). The effect of methoxychlor on the epididymal antioxidant system of adult rats. Reprod. Toxicol., 16: 161-172.

Maitra, S.K. and Sarkar, R. (1995). Morphological study of the testes in relation to the brain and testicular acetylcholinesterase activity in an organophosphate pesticide ingested wild passerine bird Lonchura malabarica. Folia Biologica., 43: 143-149.

Pino-Lataillade, G.; Thoreux-Manlay, A.; Coffigny, H.; Masse, R. and Soufir, J.C. (1995). Reproductive toxicity of chronic lead exposure in male and female mice. Hum. Exp. Toxicol., 14: 872- 881.

Presibella, K. M.; Kita, D. H.; Carneiro, C. B.; Andrade, J.M. and Dalsenter, P.R. (2005). Reproductive evaluation of two pesticides combined (deltamethrin and endosulfan) in female rats. Reprod. Toxicol., 20: 95-101.

Ratnasooriya, W.D.; Ratnayake, S.S.K. and Jayatunga, Y.N.A. (2002). Effects of pyrethroid insecticide ICON (lambda cyhalothrin) on reproductive competence of male rats. Asian J. Androl., 4(1): 3541.

Robb, G. W.; Amann, R. P. and Killian, G. J. (1978). Daily sperm production and epididymal sperm reserves of pubertal and adult rats. J. Reprod. Ferti., 54: 103-107.

Sarkar, R.; Mohanakumar, K. P. and Chowdhury M. (2000). Effects of an organophosphate pesticide, quinalphos, on the hypothalamo-pituitary-gonadal axis in adult male rats. J. Reprod. Fert., 18: 29-38.

SAS, Statistical Analysis System (1986). SAS User's Guide: Statistics, version 5 Edition SAS Inst., Inc., Cary, NC, U.S.A. 
Scollon, E.J.; Carr, J.A. and Cobb, G.P. (2004). The effect of flight, fasting and p,p0-DDT on thyroid hormones and corticosterone in Gambel's whitecrowned sparrow, Zonotrichia leucophrys gambelli. Comparative Biochemistry and Physiology. Toxicol. Pharmacol., 137: 179-189.

Steel, R.G.D. and Torrie, J. H. (1981). Principle and Procedure of Statistics. A Biometrical Approach (2nd ed.), Mc Gvaus-Hill Booh Company, New York, U.S.

WHO (1999). World health organisation. Pesticide residues in food. Joint FAO/ WHO Meeting on Pesticide Residues, Report 153.
WHO (1992), World Health Organisation. Environmental health criteria (1992), 130.

Yousef, M.I.; El-Demerdash, F.M.; Kamel, K.I. and AlSalhen, K.S. (2003a). Changes in some hematological and biochemical indices of rabbits induced by isoflavones and cypermethrin. Toxicology, 189: 223-234.

Yousef, M.I; El-Demerdash, F. M. and Al-Salhen, K. S. (2003b). Protective role of isoflavones against the toxic effect of cypermethrin on semen quality and testosterone levels of rabbits. J. Environ. Sci. Health, B38(4): 463-478. 


\section{الملخص العربي}

\section{التغير فى الخصائص الهيماتولوجية و التناسلية التاتج عن التعرض لمبيد اللورزبان في ذكور الفئران

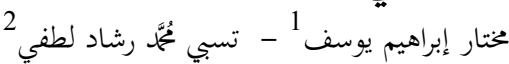

والمعدل اليومى لإنتاج الحيوانات المنوية و معدل انتقال الحيوانات المنوية

مع انخفاض مستويات التستوستيرون و ارتفاع مستويات الثيروكسين لحسين الحر في البلازما مقارنة بالمجموعة الضابطة.

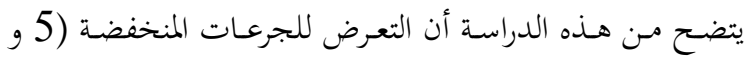

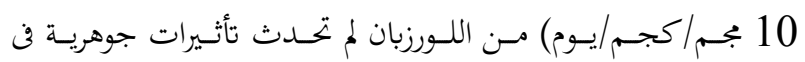
خصائص الدم و السائل المنوى و مستوى هرمونات التستوستيرون و

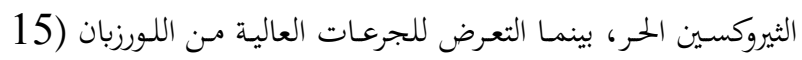

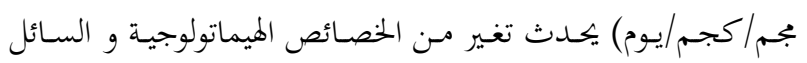

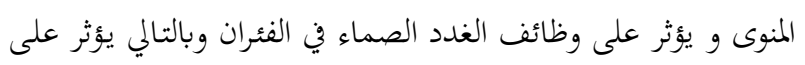

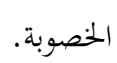

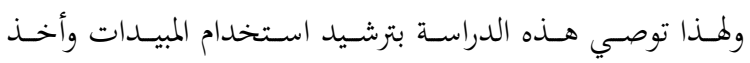

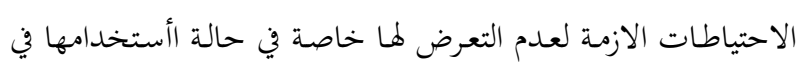

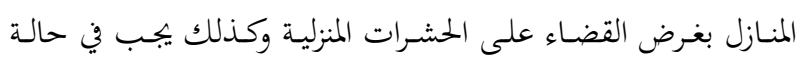

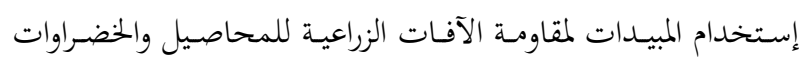
عدم الحصاد إلابعد مرور فترة زمنية حتى يتم تحلل هذه المبيدات.
يهدف هذا البحثث الى دراسة التاثيرات السـامة لجرعات مختلفة

من اللورزبان على الخصائص الهيماتولوجية ومستويات التستوستيرون والثيروكسـين وخصـائص السـائل المنـوي في ذكـور الفئران. تم معاملـة الفئران عن طريق الفم بجرعات مختلفة من اللورزبان ( 15 , 10

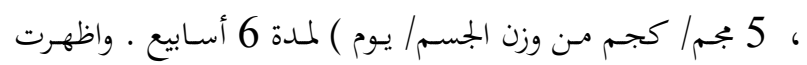

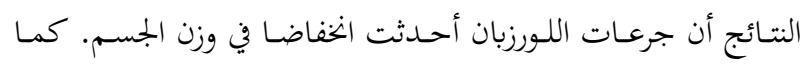
حدث انخفاض في وزن الخصية والبربخ والحويصلات المنوية في الفئران التى تمت معاملتها بجرعة 15 مجم/كجم. و و كذلك ولك أحدثت ولت المعاملة

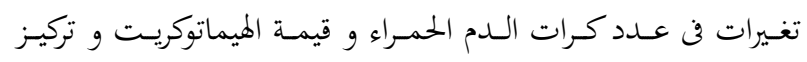

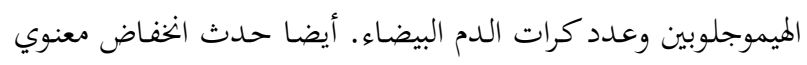

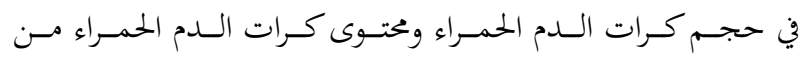

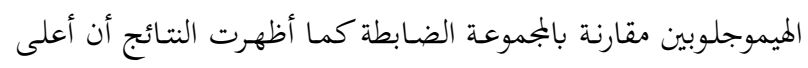

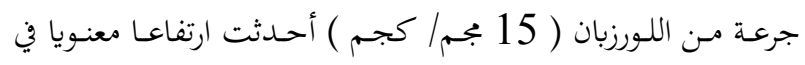

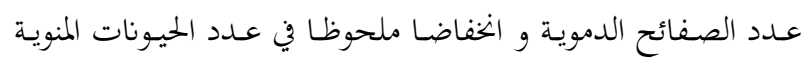
وعدد الاسبرماتيد 